\title{
Machine milking-induced changes in teat canal dimensions as assessed by ultrasonography
}

\author{
J. M. Melvin, ${ }^{1}$ W. Heuwieser, ${ }^{2,3}$ P. D. Virkler, ${ }^{2}$ D. V. Nydam, ${ }^{2}$ and M. Wieland ${ }^{2 *}$ \\ ${ }^{1}$ Department of Animal Science, Cornell University, Ithaca, NY 14853 \\ ${ }^{2}$ Department of Population Medicine and Diagnostic Sciences, Cornell University, Ithaca, NY 14853 \\ ${ }^{3}$ Clinic for Animal Reproduction, Faculty of Veterinary Medicine, Freie Universität Berlin, Königsweg 65, 14163 Berlin, Germany
}

\section{ABSTRACT}

Changes in teat canal diameter as induced by machine milking are thought to be related to teat canal penetrability and susceptibility to new intramammary infections. The objective of this study was to describe the effects of machine milking on teat canal dimensions as assessed by ultrasonography and to evaluate postmilking changes of teat canal dimensions throughout an 8-h milking interval. Ultrasonographic images were taken of the left front and right hind teats of 80 Holstein cows milked 3 times per day. Imaging occurred before attachment of the milking unit after completion of premilking udder preparation $(t-1)$, immediately after removal of the milking unit (t0), and then every hour after milking until $8 \mathrm{~h}$ had elapsed (t1 to t8). Teat canal length and teat canal diameter (at the proximal, middle, and distal regions) were measured. General linear mixed model analysis indicated differences in the relative change of teat canal length (compared with $\mathrm{t}-1$ ) with least squares means (LSM) and 95\% confidence interval (95\% CI) of $11.1 \%$ (8.7-13.4\%) after machine milking (t0). Teat canal length decreased throughout the 8-h milking interval but remained elevated relative to $t-1$. Teat canal diameter at the proximal and middle regions increased near the end of the milking interval, whereas that at the distal region did not change meaningfully during the $8 \mathrm{~h}$ of observation. Our findings suggest that the teat canal and its surrounding tissue is in a state of near-constant remodeling in cows milked 3 times daily. Future work is warranted to study the association between ultrasonographically assessed changes of teat canal dimensions after machine milking and teat canal penetrability to mastitis-causing pathogens.

Key words: machine milking, teat canal diameter, teat canal length, ultrasound

Received April 23, 2018

Accepted November 19, 2018.

*Corresponding author: mjw248@cornell.edu

\section{INTRODUCTION}

Despite widespread implementation of comprehensive control programs and research within the last decades, mastitis continues to be one of the most common diseases of dairy cows (Ruegg, 2012). Direct costs for diagnostics, therapeutics, veterinary service, labor, loss of saleable milk, and increased mortality (Seegers et al., 2003; Bar et al., 2008; Rollin et al., 2015), as well as indirect costs due to reduced milk production (Gröhn et al., 2004; Bar et al., 2008; Schukken et al., 2009), premature culling (Beaudeau et al., 1995; Gröhn et al., 1998; Cha et al., 2013), and reduced reproductive performance (Chebel et al., 2004; Santos et al., 2004; Ahmadzadeh et al., 2009) make it one of the most costly diseases for dairy producers.

The vast majority of mastitis cases are caused by IMI, with pathogenic bacteria entering the mammary gland through the teat canal. The teat canal is therefore considered the cow's primary defense against mastitis pathogens (O'Shea, 1987). Sustaining teat canal integrity and pliability of its adjacent tissues is therefore critical to resist IMI (O'Shea, 1987; Mein, 2012). It is generally agreed that machine milking induces changes (long-, medium-, and short-term) in teat canal integrity and tissue pliability (Neijenhuis et al., 2001a; Upton et al., 2016; Penry et al., 2017). Long-term changes in teat condition are the adaptation of teat tissue to machine milking over many weeks and include the degree of teat end callosity thickness and teat end callosity roughness (Neijenhuis et al., 2000). Medium-term changes appear after several days or weeks and include hemorrhaging, dry skin, and skin lesions (Mein et al., 2001). Machine milking-induced short-term changes of teat tissue condition are defined as tissue responses to a single milking (Mein et al., 2001) and can be discriminated into congestion (intravascular accumulation of fluids) and edema (extravascular accumulation of fluids; Hamann and Mein, 1990). Short-term changes have been investigated in multiple studies using different techniques, including visual assessment (Hillerton et al., 2000), a modified spring-loaded caliper (Hamann and Mein, 
1988), a 2-dimensional vision-based measuring device (Zwertvaegher et al., 2013), infrared thermography (Paulrud et al., 2005), and ultrasonography (Neijenhuis et al., 2001a). These short-term changes have been related to teat canal openness, penetrability, and susceptibility to new IMI (Zecconi et al., 1992; Neijenhuis et al., 2001a; Paulrud et al., 2005). Most studies, however, determined indirect estimates such as teat end firmness, teat end width, and teat wall thickness but did not investigate the teat canal diameter directly. The limited information on postmilking changes in teat canal diameter dimensions based on radiographic imaging dates back 4 decades (McDonald, 1975). Results may no longer apply to high-producing dairy cows and the modern dairy industry as milk yield and flow rates have changed considerably.

Because of considerable improvements in ultrasound technology, recent studies analyzing teat canal dimensions have used ultrasonography, which is less invasive than radiographic imaging and allows for imaging of tissues within the teat canal (Franz et al., 2001; Klein et al., 2005; Khol et al., 2006). Effective teat canal ultrasonography methods were first described by Franz et al. (2001). No intramammary injections were required to aid in visualization; successful imaging of the teat canal was achieved solely with the ultrasound transducer, contact gel, and a cup of water to immerse the teat and avoid its deformation. Ultrasonography-based measurements of teat canal diameter were later reported considering udder health (i.e., mastitis risk; Klein et al., 2005) and milking technique (i.e., conventional versus automatic milking system; Khol et al., 2006), and the effects of machine milking (Szencziová et al., 2013; Strapák et al., 2017; Martin et al., 2018).

To the best of our knowledge, changes in teat canal diameter that result from machine milking in cows milked 3 times per day have not yet been investigated by ultrasonography. Such studies could contribute to the understanding of how the teat canal is affected by current machine milking practices and how potential changes relate to postmilking susceptibility to new IMI. Therefore, the objective of our study was to ultrasonographically assess changes in teat canal dimensions caused by machine milking in dairy cows milked 3 times per day. The hypothesis tested in our study was that changes in teat canal dimensions would occur as a result of machine milking. In addition, we described changes in teat canal dimensions over an 8-h postmilking interval.

\section{MATERIALS AND METHODS}

This observational study was conducted at the Teaching Dairy Barn at the Cornell University College of Veterinary Medicine (Ithaca, NY) between January and February 2017. The study protocol was reviewed and approved by the Cornell University Institutional Animal Care and Use Committee (protocol no. 20160085).

\section{Animals and Housing}

Holstein cows $(\mathrm{n}=123)$ were housed year-round in 2 freestall pens with sand bedding and fed the same TMR, which was consistent with requirements outlined by the NRC (2001). Cows were milked 3 times per day at $0400 \mathrm{~h}$ (milking \#1), $1100 \mathrm{~h}$ (milking \#2), and 1900 $\mathrm{h}$ (milking \#3). Cows received recombinant bST (Posilac, Elanco Animal Health, Greenfield, IN) according to label directions.

\section{Milking System}

Cows were milked in a $2 \times 10$ parallel milking parlor (P2100, DeLaval International AB, Tumba, Sweden). The milking unit consisted of the milking cluster MC70 (weight: $2.1 \mathrm{~kg}$; DeLaval International $\mathrm{AB}$ ) and the Clover liner (Clover SR $12 \mathrm{~mm}$; DeLaval International $\mathrm{AB})$. The design characteristics of the milking liner were as follows: mouthpiece depth, $27 \mathrm{~mm}$; mouthpiece bore diameter, $20.3 \mathrm{~mm}$; barrel shape, concave; barrel length, $113 \mathrm{~mm}$; and barrel diameter at $75 \mathrm{~mm}$ (calculation: circumference $/ \pi), 22.6 \mathrm{~mm}$. The long milk tube was a silicone milk tube (90843501; DeLaval International AB) with an inner diameter of $19 \mathrm{~mm}$. The milk line was installed $75 \mathrm{~cm}$ below cow standing level. The pulsator (EP100; DeLaval International AB) was set at a pulsation rate of 60 cycles/min, a pulsation ratio of 65:35, and a side-to-side alternating pulsation. The pulsation phases were as follows: a-phase, 120; b-phase, 530; c-phase, 90; and d-phase, $260 \mathrm{~ms}$, respectively. The system vacuum was set to $46 \mathrm{kPa}$, yielding an average claw vacuum of $39 \mathrm{kPa}$ during the peak milk flow period. The udder level teat cup remover take-off milk flow threshold was set to $1.3 \mathrm{~kg} / \mathrm{min}$ (delay time: $0 \mathrm{~s}$ ). All milking system settings were verified and assessed by the investigators before the start of data collection.

\section{Milking Characteristics}

Total milk yield (TMY, kg), milking unit on time (MUOT, s), and average milk flow rate (AMF, kg/ min) were assessed at each milking with electronic milk meters (MM27; DeLaval International AB) and recorded using the herd management system ALPRO (DeLaval International AB). Electronic milk meters were calibrated before the start of data collection. 


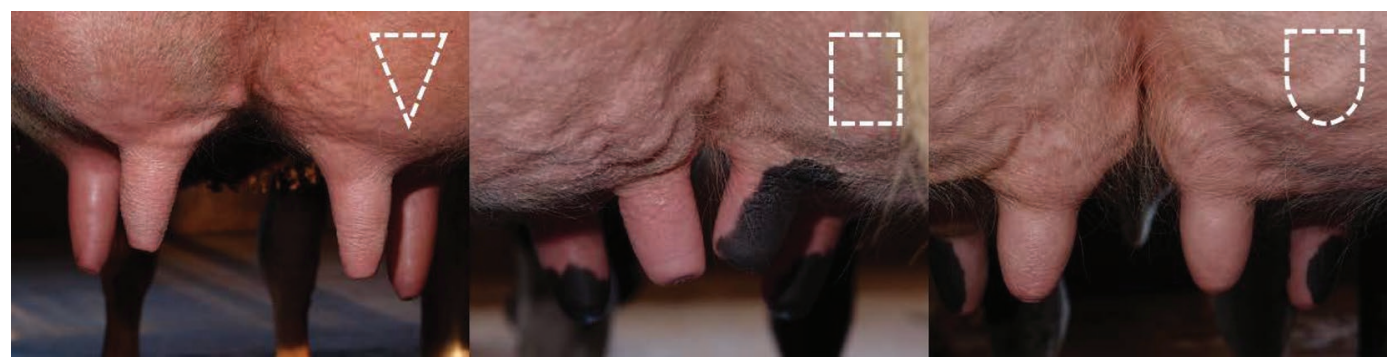

Figure 1. Classification of teat end shapes: pointed, flat, and round. Reproduced with permission from Wieland, M., D. V. Nydam, and P. D. Virkler, A longitudinal field study investigating the association between teat end shape and two minute milk yield, milking unit-on time, and time in low flow rate, Livestock Science, 205, 88-97, Elsevier, 2017.

\section{Enrollment}

Lactating cows were eligible for enrollment if they were $\geq 30$ DIM (to minimize potential confounding of results by peripartal udder edema), were free of clinical mastitis for the last $4 \mathrm{wk}$, and had no udder abnormalities such as nonlactating quarters or teat injuries. Because we anticipated that standing time would be increased during the observation period, cows were required to be free of lameness. Eligible cows $(\mathrm{n}=80)$ were randomly selected from the milking herd using the random number function in Excel (2013, Microsoft Corp., Redmond, WA) and enrolled in blocks of 8 . All cow characteristics such as parity, DIM, and 305-d mature-equivalent milk production were gathered from a dairy management software program (Dairy Comp 305, Valley Agricultural Software, Tulare, CA).

\section{Teat Characteristics}

Descriptions of teat characteristics (teat end shape, teat length, teat diameter, and teat end callosity) were recorded with a digital voice recorder (ICD-UX533BLK, Sony, San Diego, CA) during milking \#2 on the day of data collection. Measurements and evaluations were taken after completion of premilking udder preparation but immediately before milking unit attachment. The dimensions of teat length and teat diameter were assessed with a digital depth gauge (SKU 303-1752, Shars Tool Company, St. Charles, IL) and a digital caliper (75-TM54006, Vernier, Beaverton, OR), respectively. Teat length was measured from the teat base to the teat end. Teat diameter was assessed at the midpoint between the teat base and the teat end. For subsequent analyses, a new variable (i.e., teat size) was created based on the dimensions of the milking liner used in the study and classified into 1 of 3 categories as follows: small, teat length $\leq 37 \mathrm{~mm}$ or teat diameter $<23 \mathrm{~mm}$; moderate, teat length $>37 \mathrm{~mm}$ and teat diameter $23-25$ $\mathrm{mm}$; large, teat length $>37 \mathrm{~mm}$ and teat diameter $>25$ $\mathrm{mm}$. Teat end shape was classified into 1 of 3 categories as previously described (Wieland et al., 2017): pointed, flat, or round (Figure 1).

Teat end callosity was scored on a 4-point scale according to Mein et al. (2001) and classified as follows: no callosity ring present (score 1); callosity ring but no roughness present (score 2); callosity ring and roughness present, keratin fronds extending 1 to $3 \mathrm{~mm}$ from the teat orifice (score 3); and callosity ring present with excessive keratin fronds extending $\geq 4 \mathrm{~mm}$ from the teat orifice (score 4). For subsequent analyses, teat end callosity was dichotomized as follows: hyperkeratosis (HK) absent (scores 1 and 2) or HK present (scores 3 and 4).

\section{Experimental Milking}

To minimize interference with the dairy's milking schedule, study cows were milked at $1830 \mathrm{~h}$ (30 min before milking \#3) for data collection. Premilking udder preparation and teat sanitization procedures consisted of cleaning the teats with a cloth towel followed by dipping with an iodine-based teat dip (Udderdine110, Boumatic, Madison, WI). Forestripping (5 strips per teat) was carried out approximately $30 \mathrm{~s}$ after dipping. Teats were then dried with a clean cloth towel.

\section{Ultrasonographic Technique}

Teat ultrasonography of the left front and right hind teats was performed with a portable ultrasound device (Sonosite Edge, Sonosite Inc., Bothwell, WA) and a 5to $10-\mathrm{MHz}$ linear array transducer (L52; Sonosite Inc.). The optimal imaging modes were identified before the study. The exam type was musculoskeletal with a depth of $42 \mathrm{~mm}$. The highest resolution (frequency: $10 \mathrm{MHz}$ ), grayscale of 0 , brightness of 10 , and the up/right orientation were chosen. All teat scans were taken from the caudal aspect of the teat with the transducer being 
held in a caudocranial direction. This was implemented by immersion of the teat in a rectangular plastic container $(130 \mathrm{~mm} \times 60 \mathrm{~mm} \times 60 \mathrm{~mm})$ filled with approximately $400 \mathrm{~mL}$ of warm $\left(30^{\circ} \mathrm{C}\right) 0.5 \%$ chlorhexidine solution (Vet One, Boise, ID). Ultrasound gel (Medline Industries Inc., Northfield, IL) was used as a coupling medium between the transducer and the container. The teat canal was screened from one side to the other by moving the transducer and container on a lateromedial line until the widest diameter was visualized. When all teat structures were clearly visible, an image was stored.

Teat scans were taken after completion of premilking udder preparation before milking unit attachment $(\mathbf{t}-\mathbf{1})$ and directly after unit detachment (to) in the milking parlor. Ultrasonographic scanning at $\mathrm{t}-1$ commenced between 60 and $90 \mathrm{~s}$ after initiation of forestripping. Scanning and subsequent drying of teats resulted in a preparation lag time of approximately 150 $\mathrm{s}$ (mean $\pm \mathrm{SD}: 146 \pm 24 \mathrm{~s}$, range: $110-250 \mathrm{~s}$ ) from the first strip until milking unit attachment. Postmilking iodine-based teat dip (Udderdine110, Boumatic) was applied before cows were moved to the adjacent tiestall barn. Ultrasonographic scanning was then performed at $1,2,3,4,5,6,7$, and $8 \mathrm{~h}$ (t1 to t8) after milking unit detachment.

\section{Ultrasonographic Image Analysis}

Teat dimensions measured were teat canal length (TCL), proximal teat canal diameter (PROX), teat canal diameter at the midpoint between the proximal and the distal ends of the teat canal (MID), and distal teat canal diameter (DIS). Images were evaluated visually in Windows Photo Viewer (Microsoft Corp.) and classified by the first author into 1 of 2 categories: good (all boundaries clear and distinct or one blurry boundary) or poor (more than one blurry boundary). Only images classified as good were considered for further analysis. All measurements were performed by the first author using an open source software program (ImageJ, National Institutes of Health, Bethesda, MD) according to a standard operating procedure that was developed before the study and can be found elsewhere (Wieland et al., 2018b). The teat canal is a longitudinal, solid, cylinder-shaped structure (Paulrud, 2005) that is sonographically characterized by a hyperechoic line (representing the stratum corneum), which is bordered on each side by a parallel hypoechoic band (representing the stratum granulosum; Franz et al., 2001). Measurements of dimensions were performed using the straightline tool. Teat canal length was defined as the distance of the hyperechoic line between the proximal end of the teat canal at the aspect of the Furstenberg's rosette and the distal end of the teat at the aspect of the teat orifice. The midpoint of the teat canal was indicated by the straight-line tool with a white dot. A landmark was set at this point with the pencil tool (width = 3 ), and a line used to assess TCL was drawn with the draw function. This reference ascertained perpendicular measurements of the teat canal diameter at the 3 positions. The teat canal diameter was defined as the distance between the lateral boundaries of the opposing hypoechoic bands of the teat canal. The MID was measured perpendicular to the TCL at the midpoint between the proximal and the distal ends of the teat canal. The PROX was measured perpendicular to the TCL at the midpoint between MID and the proximal end of the TCL. The DIS was measured perpendicular to the TCL at the midpoint between MID and the distal end of the TCL. These positions were identified using the straight-line tool, and landmarks were set with the pencil tool. Figure 2 illustrates measured teat dimensions.

\section{Analytical Approach}

Data were maintained in a commercially available spreadsheet (Excel 2013, Microsoft Corp.) and analyzed using SAS software (version 9.4, SAS Institute Inc. Cary, NC).

Baseline Characteristics. Descriptive statistics of 305-d mature-equivalent milk production, DIM, teat length, teat diameter, ultrasound-based measurements of teat canal dimensions, and milking characteristics were generated with PROC MEANS. For subsequent analysis, DIM were stratified into 3 categories (30-100, 101-200, and >200 DIM). Frequency distributions for parity, teat end shape, teat size, and HK were assessed using PROC FREQ. Correlations between externally measured teat dimensions (teat length and teat diameter) and ultrasonographically assessed teat canal dimensions at $\mathrm{t}-1$ were determined using Pearson correlation coefficients (r) with PROC CORR. Results of correlation coefficients were classified as negligible (0.00-0.09), weak (0.10-0.39), moderate (0.40-0.69), strong $(0.70-0.89)$, and very strong correlation $(0.90-$ 1.00) according to Schober et al. (2018).

Teat Ultrasonography. To test the hypothesis that ultrasonographically assessed teat canal dimensions change during machine milking, the relative change (RC; \%) of the outcome variables of interest (TCL, PROX, MID, and DIS) compared with premilking value at $\mathrm{t}-1$ was calculated as follows:

Relative change $(\mathrm{RC})=\left[\left(\right.\right.$ Measurement $_{(\mathrm{t} 0-\mathrm{t} 8)}$

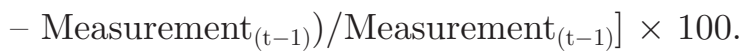


Separate general linear mixed models for each dependent variable [relative change of TCL (RCTCL), PROX (RCPROX), MID (RCMID), and DIS (RCDIS)] were generated with PROC MIXED. The following steps were consistent for all 4 models. Cow was included as random effect to account for clustering of quarter within cow. A REPEATED statement for quarter position nested within cow was included to account for repeated measurements ( $t-1$ to $t 8)$. Three covariance structures were tested (spatial power law, Gaussian, and spherical) to model the covariance of unequally spaced repeated measures, and the covariance structure with the smallest Akaike's information criterion was selected. Time of measurement was forced into the model as a fixed effect. The following additional independent variables were screened for inclusion into each model initially through univariable analysis: parity (first, second, and $\geq$ third lactation), DIM (30-100, 101-200, and >200), quarter position (left front and right hind), teat end shape (pointed, flat, and round), teat size (small, moderate, and large), HK (present and absent), AMF (kg/min), and MUOT (s). All variables with a $P$-value $<0.20$ in this step were offered as covariates in the initial models and removed by manual backward elimination to reach the final model for each outcome of interest. Finally, all remaining variables were tested for 2-way interactions. Differences in the relative change of measured teat canal dimensions were assessed by comparison of all postmilking (t0 to t8) least squares means (LSM) values derived from the above described statistical models with the premilking value (i.e., 0). Tukey-Kramer's post hoc test was used to control for experiment-wise error rate. Significance for all statistical tests was declared at $P$-value $<0.05$. For all final models, the assumptions of homoscedasticity and normality of residuals were assessed by inspection of plots of residuals versus corresponding predicted values and examination of quantile-quantile (Q-Q) plots of residuals.

\section{RESULTS}

\section{Description of Study Population}

Eighty cows were enrolled in the study, and 160 teats were ultrasonographically imaged. Each teat was imaged at 10 time points ( $\mathrm{t}-1$ to $\mathrm{t} 8$ ). A total of 67 images $(4.2 \%)$ were missing and 112 images $(7.0 \%)$ were excluded from the final analysis because of poor quality. A total of 1,421 images remained for final analyses.

\section{Baseline Characteristics}

The mean \pm SD (median; range) 305-d matureequivalent milk production of all 80 cows was $14,137 \pm$ $2,010(14,047 ; 9,925$ to 18,520$) \mathrm{kg}$. Mean $( \pm \mathrm{SD})$ DIM was $196 \pm 92 \mathrm{~d}$, ranging from 30 to $445 \mathrm{~d}$. Parity was distributed as follows: $25(31 \%)$ were in first, $30(38 \%)$ were in second, and $25(31 \%)$ animals were in third or greater lactation (10 in third, 8 in fourth, 4 in fifth, and 3 in sixth lactation).

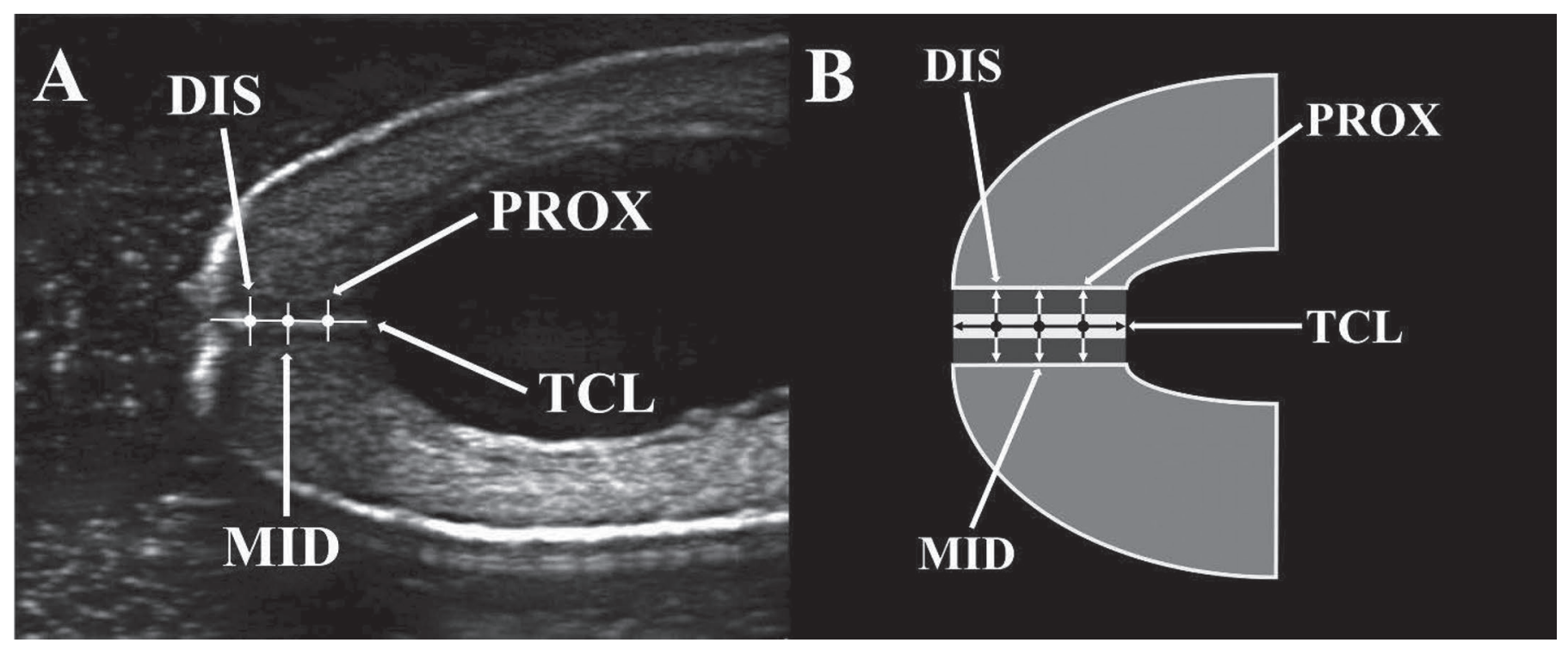

Figure 2. Measurements of teat canal dimensions of sonographic teat scan showing original image (A) and schematic for illustration of boundaries (B): teat canal length (TCL), proximal teat canal diameter (PROX), teat canal diameter at the midpoint between the proximal and the distal ends of the teat canal (MID), and distal teat canal diameter (DIS). 
Table 1. Frequency distribution of teats considering teat end shape, teat length, teat diameter, and presence or absence of teat end hyperkeratosis stratified by quarter position in 80 cows

\begin{tabular}{|c|c|c|c|c|}
\hline \multirow{3}{*}{$\begin{array}{l}\text { Teat } \\
\text { characteristic }\end{array}$} & \multicolumn{4}{|c|}{ Quarter position } \\
\hline & \multicolumn{2}{|c|}{ Left front } & \multicolumn{2}{|c|}{ Right hind } \\
\hline & $\mathrm{n}$ & $\%$ & $\mathrm{n}$ & $\%$ \\
\hline \multicolumn{5}{|l|}{ Teat end shape } \\
\hline Pointed & 10 & 12.50 & 7 & 8.75 \\
\hline Flat & 8 & 10.00 & 11 & 13.75 \\
\hline Round & 62 & 77.50 & 62 & 77.50 \\
\hline \multicolumn{5}{|l|}{ Teat size ${ }^{1}$} \\
\hline Small & 10 & 12.50 & 18 & 22.50 \\
\hline Moderate & 25 & 31.25 & 32 & 40.00 \\
\hline Large & 45 & 56.25 & 30 & 37.50 \\
\hline \multicolumn{5}{|l|}{ Hyperkeratosis } \\
\hline Absent & 33 & 41.25 & 52 & 65.00 \\
\hline Present & 47 & 58.75 & 28 & 35.00 \\
\hline
\end{tabular}

${ }^{1}$ Teat size: small $=$ teat length $<37 \mathrm{~mm}$ or teat diameter $<23 \mathrm{~mm}$ moderate $=$ teat length $>37 \mathrm{~mm}$ and teat diameter $23-25 \mathrm{~mm}$; large $=$ teat length $>37 \mathrm{~mm}$ and teat diameter $>25 \mathrm{~mm}$.

The mean \pm SD (median; range) TMY during experimental milkings when ultrasonographic scanning was performed was $10.4 \pm 2.9(10.6 ; 3.4$ to 17.6$) \mathrm{kg}$. Mean $\pm \mathrm{SD}$ (median; range) AMF was $3.1 \pm 0.9$ (3.0; 0.9 to 5.1$) \mathrm{kg} / \mathrm{min}$, and mean $\pm \mathrm{SD}$ (median; range) MUOT was $210 \pm 69(201 ; 101$ to 469$)$ s.

The mean $\pm \mathrm{SD}$ (median; range) lengths for left front and right hind teats were $53.2 \pm 7.2(53 ; 35$ to 72$)$ and $44.9 \pm 6.0$ (44; 30 to 59$) \mathrm{mm}$, respectively. Mean $( \pm$ SD) diameters for left front and right hind teats were $26.4 \pm 3.8$ (26; 18 to 36$)$ and $25.1 \pm 3.0(25 ; 16$ to 32$)$ $\mathrm{mm}$, respectively. Table 1 provides the frequency distribution of teat end shape, teat size, and HK stratified by quarter position.

Pearson correlation coefficients and corresponding $P$-values between externally measured teat dimensions (teat length and teat diameter) and ultrasonographically assessed teat canal dimensions are depicted in Supplemental Table S1 (https://doi.org/10.3168/jds .2018-14968). Teat length was weakly correlated with teat diameter $(\mathrm{r}=0.35, P<0.0001)$ and TCL $(\mathrm{r}=$ $0.26, P=0.002)$, whereas no correlation was observed between teat length and teat canal diameter dimensions $(\mathrm{r} \leq|0.10|, P \geq 0.24)$. Teat diameter was not correlated with ultrasonographically measured dimensions of the teat canal ( $\mathrm{r} \leq|0.10|, P \geq 0.23)$. Teat canal length was weakly correlated with PROX $(\mathrm{r}=0.17, P=0.04)$ and MID ( $\mathrm{r}=0.19, P=0.02)$, whereas no correlation was found between TCL and DIS $(\mathrm{r}=0.04, P=0.64)$. Correlations were moderate between PROX and MID $(\mathrm{r}=0.67, P<0.0001)$ and MID and DIS $(\mathrm{r}=0.49, P$ $<0.0001)$, whereas a weak correlation was documented between PROX and DIS $(\mathrm{r}=0.37, P<0.0001)$.

\section{Teat Canal Dimensions}

The association of machine milking and ultrasonographically assessed teat canal dimensions was evaluated based on the 4 ultrasonographically assessed outcomes: RCTCL, RCPROX, RCMID, and RCDIS. Average values (mean \pm SD) of TCL, PROX, MID, and DIS stratified by time are provided in Table 2. Results of general linear mixed models for each outcome variable are described separately below, demonstrated in Table 2, and illustrated in Figure 3.

TCL. The mean $\pm \mathrm{SD}$ (median; range) TCL was $14.24 \pm 2.26$ (14.07; 7.28 to 21.75$) \mathrm{mm}$. The final model for RCTCL contained time $(P<0.0001)$ and parity $(P$ $=0.007$ ). Controlling for the effect of time, RCTCL was 12.3 (8.6 to 16.0$), 5.6$ (2.3 to 8.9$)$, and 4.6 (1.0 to 8.1$) \%$ in teats from cows in first, second, and third or greater lactations, respectively, and was different between cows in first and second lactation $(P=0.02)$ and between cows in first and third or greater lactation $(P=0.01)$.

$P R O X$. The mean $\pm \mathrm{SD}$ (median; range) $\mathrm{PROX}$ was $2.10 \pm 0.48(2.06 ; 1.02$ to 3.99$) \mathrm{mm}$. The final model for RCPROX contained time $(P=0.02)$ and quarter position $(P<0.0001)$. Controlling for the effect of time, RCPROX was 7.0 (3.6 to 10.3) and -1.9 ( -5.3 to 1.5 ) $\%$ in left front and right hind teats, respectively.

MID. The mean $\pm \mathrm{SD}$ (median; range) MID was $1.94 \pm 0.41(1.92 ; 0.86$ to 3.45$) \mathrm{mm}$. The final model for RCMID contained time $(P=0.18)$ and HK $(P=$ 0.002). Controlling for the effect of time, RCMID was -0.8 ( -5.1 to 3.5 ) and 8.1 (3.7 to 12.6$) \%$ in teats without and with HK, respectively.

DIS. The mean \pm SD (median; range) DIS was 1.72 $\pm 0.46(1.69 ; 0.48$ to 3.93$) \mathrm{mm}$. The final model for RCDIS contained the following independent variables: time $(P=0.59)$, quarter position $(P=0.04)$, and teat end shape $(P=0.02)$. Controlling for all other variables included in the model, RCDIS was 5.8 (1.0 to 10.7) and 0.58 ( -4.3 to 5.4$) \%$ in left front and right hind teats, respectively. The RCDIS was 1.9 ( -9.0 to 12.7$)$, 18.4 (6.9 to 29.9 ), and 1.1 ( -3.4 to 5.6 ) \% in pointed, flat, and round teats, respectively, and was different between pointed and flat teats $(P=0.04)$ and between flat and round teats $(P=0.006)$.

\section{DISCUSSION}

The objective of the study was to describe changes in ultrasonographically assessed teat canal dimensions that occur after machine milking and throughout an 8-h milking interval. The sample was obtained from a high-producing herd with a thrice-daily milking schedule to best represent current milking practices in modern dairy herds in the United States. 
MACHINE MILKING AND TEAT CANAL DIMENSIONS

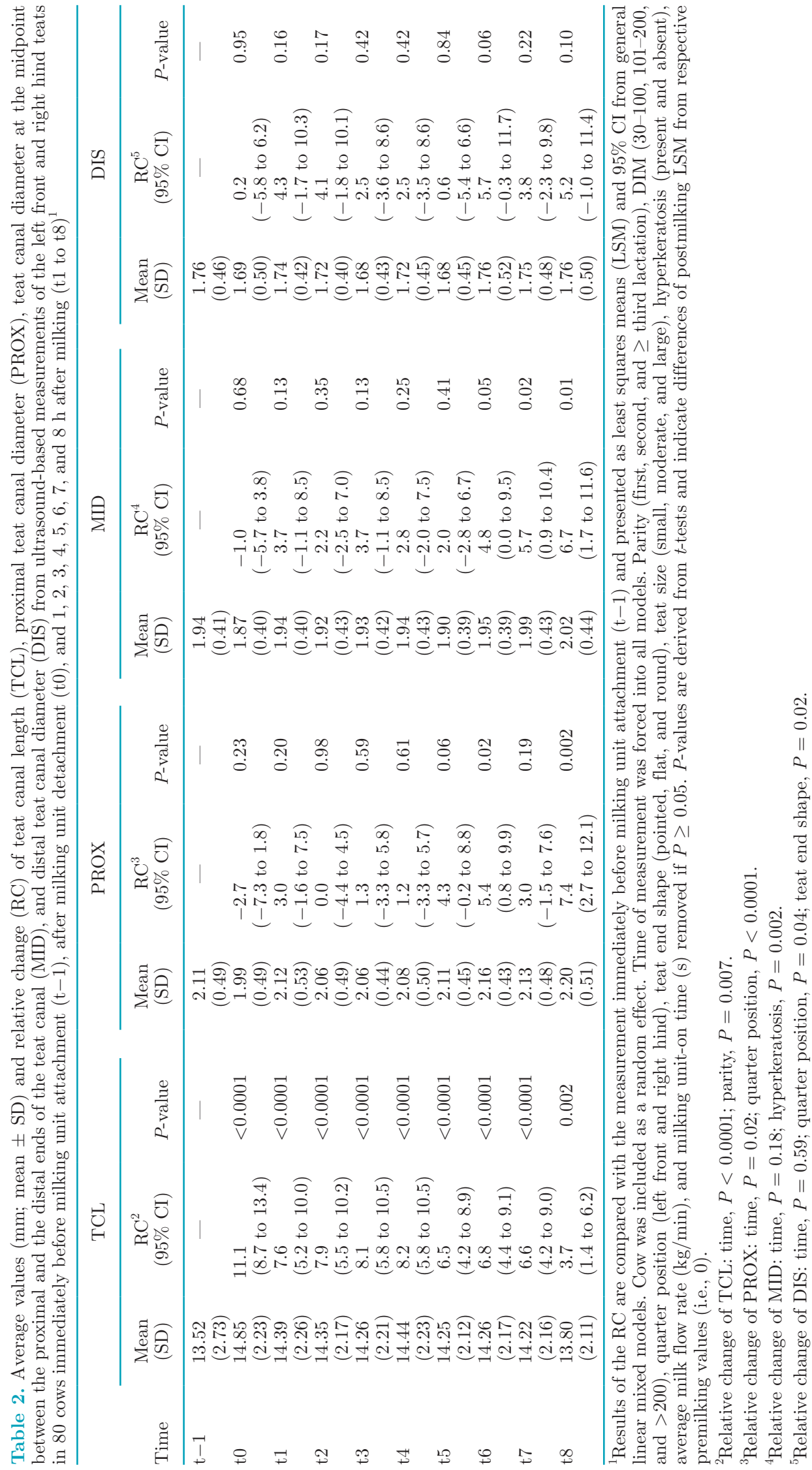




\section{Average Teat Canal Dimensions}

In the present study, the average TCL ranged from 13.52 to $14.85 \mathrm{~mm}$, depending on the time of measurement. Our recorded TCL values were generally higher than those described in other ultrasonographic studies, which reported average TCL ranges of 8.76 to 11.15 $\mathrm{mm}$ (dependent upon milking method and DIM; Khol et al., 2006), 10.731 to $13.137 \mathrm{~mm}$ (dependent upon time of measurement; Szencziová et al., 2013), and 9.36 to $12.86 \mathrm{~mm}$ (dependent upon teat placement and time of measurement; Strapák et al., 2017). Data from Klein et al. (2005) are somewhat closer to our findings, with an average TCL of $17.0 \mathrm{~mm}$ and a range of 8.0 to $24.0 \mathrm{~mm}$. Average teat canal diameters ranged from 1.68 to $2.20 \mathrm{~mm}$, depending upon the region of the teat canal being measured and the time of recording in the current study. This range is supported by recent ultrasonographic studies of the teat canal that reported an overall average teat canal diameter of 1.9 $\mathrm{mm}$ (Klein et al., 2005) and average diameters of 1.24 to $1.53 \mathrm{~mm}$, depending on DIM and milking system
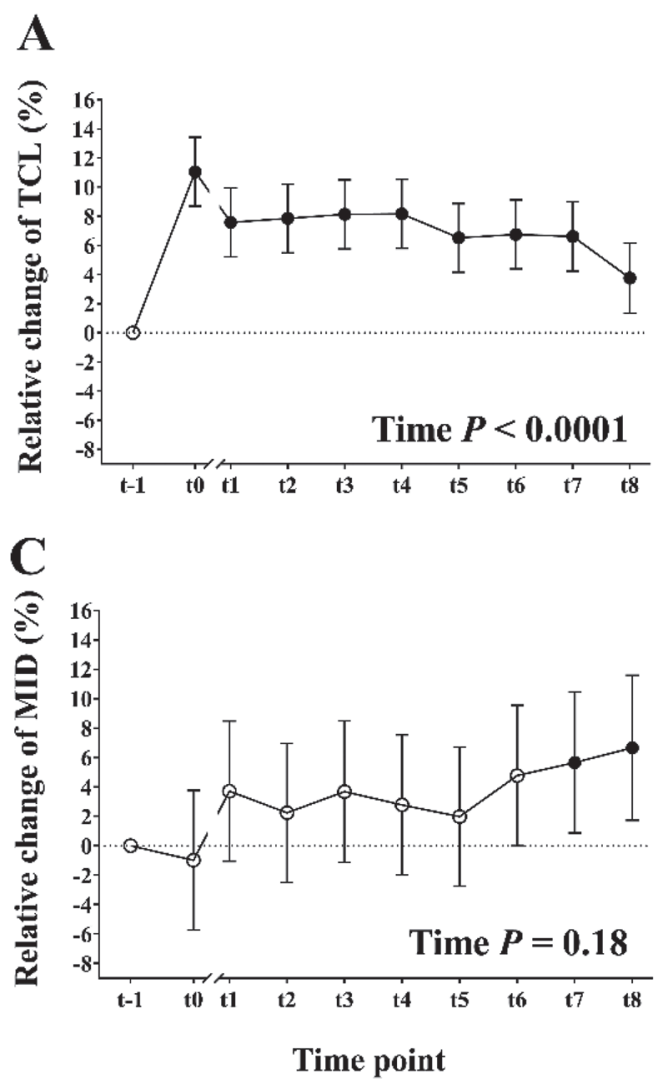

(Khol et al., 2006). These values, however, stand in contrast to those reported in 3 more recent studies that documented ranges of 0.66 to $0.78 \mathrm{~mm}$ (Szencziová et al., 2013), 1.09 to $1.11 \mathrm{~mm}$ (Strapák et al., 2017), and 0.99 to 1.22 (Martin et al., 2018), depending on the time of recording.

\section{Changes in Teat Canal Dimensions During Machine Milking}

We found that TCL changed as a result of machine milking, with an average increase of $11.1 \%$ at t0 ( $P$ $<0.0001)$ compared with the premilking value $(\mathrm{t}-1)$. The findings of our study are consistent with those of Neijenhuis et al. (2001a), who reported an average relative increase of $12 \%$ in TCL immediately after milking. Other researchers reported an average elongation of the TCL of 19\% (Martin et al., 2018), 20.5 and 32.9\% in front and hind teats, respectively (Strapák et al., 2017), 27\% (Szencziová et al., 2013), and 30 to 41\% (Paulrud et al., 2005).
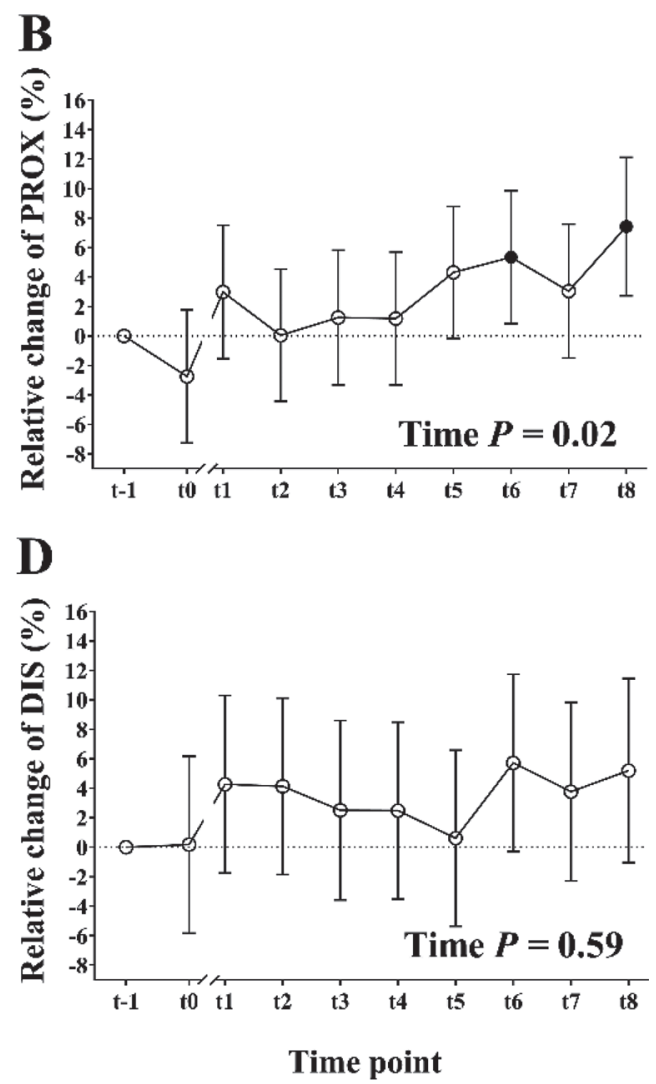

Figure 3. Relative change of teat canal length (TCL; A), proximal teat canal diameter (PROX; B), teat canal diameter at the midpoint between the proximal and the distal ends of the teat canal (MID; C), and distal teat canal diameter (DIS; D) of the left front and the right hind teats in 80 cows measured immediately after milking unit detachment (t0) and at 1,2,3,4,5,6, 7, and 8 h after milking (t1 to t8) compared with the measurement immediately before milking unit attachment $(\mathrm{t}-1)$. Results are presented as least squares means (\%) of general linear mixed models; error bars show $95 \%$ confidence intervals. Solid symbols indicate a difference from 0 (horizontal dotted line) at $P<0.05$. 
In contrast, teat canal diameters were not meaningfully different after machine milking at t0 $(P \geq 0.23)$. Our findings differ from the results first described by McDonald (1975), which indicated a decrease in the teat canal diameter in all 3 regions between t0 and t2. The author did not report premilking values for the teat canal diameters, likely because visualization on radiographs requires a barium sulfate injection into the teat. Because of this, comparisons cannot be made between McDonald's (1975) data and the present study regarding changes during the milking process $(t-1$ to t0). Recent studies provide more similar ultrasonographic investigations of changes in teat canal diameter dimensions relative to machine milking (Szencziová et al., 2013; Fasulkov et al., 2014; Strapák et al., 2017; Martin et al., 2018). The researchers measured teat canal diameter dimensions at the midpoint between the proximal and distal ends of the teat canal (Szencziová et al., 2013; Fasulkov et al., 2014; Strapák et al., 2017) or $5 \mathrm{~mm}$ distal to the Furstenberg's rosette (Martin et al., 2018). In addition to assessing the teat canal diameter, Martin et al. (2018) assessed the width of the distal teat canal orifice. The authors observed an average postmilking teat canal diameter increase of 17\% (Szencziová et al., 2013) and an increase of 9.0 and $9.1 \%$ in front and hind teats, respectively (Strapák et al., 2017). Martin et al. (2018) reported a $22.6 \%$ increase in teat canal diameter and a $28.9 \%$ increase in distal teat canal orifice. In contrast, Fasulkov et al. (2014) observed a decrease in teat canal diameter of $9.9 \%$, from 1.92 to $1.73 \mathrm{~mm}$.

\section{Changes in Teat Canal Dimensions Throughout the Milking Interval}

Teat canal length remained elevated after $8 \mathrm{~h}(\mathrm{t} 8$, $P=0.002)$ compared with the premilking value $(\mathrm{t}-1)$ in this study. Our results are consistent with findings of Neijenhuis et al. (2001a), who reported a sustained elevation of TCL above its premilking value throughout an 8-h observation period. Similar findings were documented by Gleeson et al. (2002). The investigators recorded TCL before milking, after removal of the milking cluster, and every hour until $5 \mathrm{~h}$ had elapsed. They found that TCL did not return to premilking values during the observation period. In contrast, Paulrud et al. (2005) found that postmilking recovery of TCL varied based on the type of milking liner used, with softer liners being related to faster (i.e., $<20 \mathrm{~min}$ ) recovery times during the 20 -min observation period. In a recent study, we showed that recovery of TCL was associated with teat end shape such that TCL returned to premilking values in $7 \mathrm{~h}$ in teats with pointed teat end shapes and in $1 \mathrm{~h}$ in teats with flat teat end shapes;
TCL remained increased in round teats throughout the $7 \mathrm{~h}$ of observation (Wieland et al., 2018a). Together, these findings and those of the current study suggest that, under certain milking liner and machine conditions, the 8-h milking interval resulting from a thricedaily milking schedule does not allow the teat canal adequate time to recover from changes caused by machine milking in cows with certain teat characteristics. This frequency of milking could cause teat tissue alteration that is never fully restored, potentially placing the teat in a state of near-constant remodeling.

In this study, teat canal diameter dimensions remained unchanged during the milking interval except between $\mathrm{t} 6$ and $\mathrm{t} 8$, when PROX (t6, $P=0.02$; $\mathrm{t} 8, P=$ $0.002)$ and MID (t7, $P=0.02 ; \mathrm{t} 8, P=0.01)$ exceeded the original premilking values. This observation was likely a result of intramammary pressure, as suggested by McDonald (1975) and Hamann and Mein (1990). The accumulation of milk in the teat cistern during the milking interval can increase pressure, causing expansion of the teat canal diameter, most noticeably at the proximal end. Our theory is further supported by previous studies showing that the teat cistern width increased after milking and exceeded the premilking values at $8 \mathrm{~h}$ (Neijenhuis et al., 2001a) and $7 \mathrm{~h}$ (Wieland et al., 2018a) after milking. The results of these studies also suggest that, under similar study conditions, the pressure within the teat cistern was at its maximum value at the end of the observation period. This pressure may promote expansion of and movement of milk into the teat canal, which might explain our observation of the highest values for PROX and MID occurring at $t 8$ rather than at $t-1$. To our knowledge, no study has ultrasonographically assessed and described teat canal diameter dimensions over an 8-h postmilking interval. Other investigators recorded teat canal diameter dimensions for $1 \mathrm{~h}$ (Szencziová et al., 2013) or 2 h (Fasulkov et al., 2014; Strapák et al., 2017) after milking and reported that the teat canal diameter returned to premilking values by $1 \mathrm{~h}$ (Szencziová et al., 2013; Fasulkov et al., 2014) and 2 h (Strapák et al., 2017), respectively.

The disparity between the relative changes in TCL and teat canal diameter dimensions suggests that, in the current study, the longitudinal shear forces affecting TCL during machine milking had a greater effect on teat dimensions than the radial vacuum forces affecting teat canal diameter. When a milking vacuum is applied to a teat, the stress generated on the teat's longitudinal axis can fracture the keratin lining of the teat canal and create congestion and edema of the teat end tissue, preventing the elastic recoil of the teat canal after milking (Williams and Mein, 1982). In comparing TCL and teat end width changes after milking, Nei- 
jenhuis et al. (2001a) observed larger changes in TCL and attributed this phenomenon to increased pliability of the teat or increased stress applied to the teat longitudinally. Variability was also likely higher with teat canal diameter measurements. Because these measurements were smaller than TCL values, small changes in cursor placement during measurement corresponded to proportionally larger changes in the recorded teat canal diameter value. This larger variability makes it more difficult to accurately and consistently record teat canal diameters compared with TCL values.

\section{Associations Between Changes in Teat Canal Dimensions and Cow Characteristics}

We observed higher RCTCL in first-lactation animals than in cows in second $(P=0.02)$ and third or greater lactation $(P=0.01)$. These findings are of particular importance because they suggest that the effects of machine milking are most severe in teats of first-lactation animals. Future research should therefore investigate measures to alleviate the negative effects of machine milking in primiparous animals. One possible explanation is that machine milking induces changes in teat tissue composition over time. That is, accumulation of edema fluid and lymphatic by-products may lead to collagen deposition and fibrosis of the teat tissue, which could limit the pliability of the tissue with advancing lactations (Hamann and Burvenich, 1994). Our findings are similar to those of Martin et al. (2018), who reported a relative change in TCL of $20.8 \%$ (from 10.1 $\mathrm{mm}$ before to $12.2 \mathrm{~mm}$ after milking) in primiparous cows compared with $18.5 \%$ (from $10.8 \mathrm{~mm}$ before to $12.8 \mathrm{~mm}$ after milking) in multiparous cows. Those authors suggested that mechanical forces during machine milking contribute to increasing TCL and other internal teat dimensions with increasing lactations, as observed in previous studies (Klein et al., 2005; Szencziová et al., 2013), and they emphasized the importance of monitoring the influence of machine milking on teat tissue with advancing age.

Quarter position was associated with the relative change in teat canal diameter dimensions. The values of RCPROX $(P<0.0001)$ and RCDIS $(P=0.04)$ were greater in front teats than in hind teats, indicating the importance of discriminating quarter position in studies investigating the influence of machine milking on teat tissue condition. This is in accordance with previous work from our own group (Wieland et al., 2018a) and other researchers (Neijenhuis et al., 2001a), indicating that machine milking-induced changes in teat tissue parameters were more severe in front than in hind teats. Using a translucent measuring ruler, Guarín and Ruegg (2016) found a greater relative change of teat barrel diameter in front teats compared with hind teats. In contrast, Strapák et al. (2017) found greater relative changes of TCL and teat canal diameter in hind teats compared with front teats. Discrepancies between studies may be due to differences in study population, milking schedule, machine settings, and observational technique.

In the current study, the RCMID was greater in teats with HK, which could leave cows with hyperkeratotic teats more susceptible to pathogen entry via the teat canal. This result provides further evidence for the findings of Neijenhuis et al. (2001b), who found that cows with clinical mastitis had greater teat end callosity than cows without clinical mastitis. Such a relationship is further supported by Klein et al. (2005), who reported that a greater teat canal diameter was associated with higher incidence of mastitis. In contrast, no association was observed between HK and RCDIS ( $P=$ 0.88 , univariable analysis; data not shown), which is an unexpected finding and difficult to explain.

Additionally, our results showed that teat end shape was associated with RCDIS, such that flat teats had the largest RCDIS. This relationship between teat characteristics and teat canal diameter could explain differences in the incidence of mastitis. Hodgson and Murdock (1980) found that cows with flat teats had the highest average SCC (420,000 cells/mL) compared with cows with pointed or round teats. However, there is no consensus yet on the potential relationship between teat characteristics, hyperkeratosis, and incidence of mastitis. Several authors reported that teat end shape (Chrystal et al., 1999, 2001) or teat shape (Guarín et al., 2017) was not associated with SCC, and Neijenhuis et al. (2001b) found that pointed teats had the greatest teat end callosity. The findings of Guarín and Ruegg (2016), however, indicate that the risk for acquiring subclinical mastitis increases as the diameter of the teat apex increases, and Guarín et al. (2017) reported that greater teat apex diameter of front teats was associated with higher SCC. Because mastitis risk was not assessed in our study, our theories remain speculative. Further study of these characteristics is required to validate the suggested relationships.

\section{Correlations Between Externally Measured Teat Dimensions and Teat Canal Dimensions}

In comparing externally measured teat dimensions and ultrasonographically assessed teat canal dimensions, we found significant correlations between teat length and teat diameter $(P<0.0001)$ and between teat length and TCL $(P=0.002)$. These relationships are in contrast to the findings of Weiss et al. (2004), who reported no significant correlations between the 
aforementioned teat characteristics. No relationship was found between teat diameter and internal teat canal dimensions $(P \geq 0.23)$. This is in accordance with observations from Weiss et al. (2004), who observed no correlation between teat diameter and teat canal length. Our findings indicate weak correlations between TCL and PROX $(P=0.04)$ and between TCL and MID $(P=0.02)$, such that wider PROX and MID are associated with longer TCL-a relationship that has yet to be thoroughly explored. Martin et al. (2018) found a relationship between TCL and distal teat canal dimensions such that distal teat canal surface and perimeter increased with increasing TCL, but a correlation between TCL and teat canal diameter was not reported. Weiss et al. (2004) related TCL to external teat characteristics and reported a correlation between TCL and teat wall thickness but did not assess relationships of TCL with other internal teat canal diameter dimensions. Furthermore, our data indicate a significant relationship between PROX, MID, and DIS $(P<0.0001)$. As expected, correlations were stronger between adjacent dimensions (i.e., PROX and MID, $\mathrm{r}$ $=0.67$; MID and DIS, $r=0.49)$ than between PROX and DIS $(\mathrm{r}=0.37)$.

\section{Limitations and Future Research}

Changes in teat canal dimensions are reported to be associated with penetrability of the teat canal and susceptibility to mastitis-causing pathogens. Schultze and Bright (1983) found penetrability of the teat canal to Escherichia coli endotoxin to be greatest immediately after milking and lowest at $2 \mathrm{~h}$ after milking. Hamann et al. (1994) related these findings to those reported by McDonald (1975), and comparison of these data sets indicated that penetrability was greatest when the teat canal was at its largest diameter. We did not observe a decrease in teat canal diameter between $\mathrm{t} 0$ and $\mathrm{t} 2$, but significant changes were observed for TCL, with the highest TCL being recorded immediately after milking at t0. Additionally, our results indicate that teats with longer TCL also have wider PROX and MID. The changes seen in TCL could be related to varying penetrability of the teat after milking, and previous studies have related TCL and mastitis incidence. Klein et al. (2005) found that, within the same breed, longer TCL was associated with healthy teats, whereas shorter TCL was associated with infected teats. This association, however, was not tested at different time points throughout the milking interval. Grindal et al. (1991) suggested an inverse relationship between TCL and infection risk. Further research is warranted to determine the biological relevance of changes in teat canal dimensions as assessed by ultrasonography and their association with penetrability to mastitis-causing pathogens. This future work could aid in understanding the significance of changes in teat canal dimensions in relation to penetrability and help improve protocols related to decreasing the risk of new IMI.

Study variations in population, milking schedule, machine settings, and ultrasonographic image capture and analysis might explain the discrepancies noted in average values and changes in teat canal dimensions relative to milking. In the present study, we did not detect changes in teat canal diameter using the described technique. Further refinement of the teat canal diameter measuring technique may be warranted to improve consistency and decrease variability across different study methods. Possible factors that could improve the reliability of ultrasound-based measurements include the resolution of the ultrasound device, the operating procedure for the ultrasonographic technique, the study population (e.g., teat skin condition), the image analysis, and the delineation of image boundaries (i.e., inclusion of the hypoechoic bands).

We designed the study procedures to minimize potential stress to the cows or changes in their daily routines. Some factors, however, might have affected the observed results. Enrolled cows were brought into the milking parlor 30 min earlier than the normal start time for milking \#3, and these cows stood in the parlor for a longer period than usual as ultrasonographic images were recorded. After the observational milking, the cows were held for $8 \mathrm{~h}$ in tiestalls, which differed from their typical freestall housing. Teats were also repeatedly dipped in warm chlorhexidine solution as part of the ultrasound procedure. These manipulations may have had an impact on naturally occurring teat contractions, thus potentially interfering with teat canal dimensions. Some mention should be made of the decision to relate postmilking teat canal measurements to premilking measurements that were taken after completion of, rather than before, premilking udder preparation. The manipulations during premilking udder preparation likely affected measured teat canal dimensions at $\mathrm{t}-1$ such that these measurements may not fully represent a resting state of the teat canal and its surrounding tissues. Consequently, teat canal dimensions may not have returned to their premilking values until after completion of premilking udder preparation for the following milking session in this study. However, taking t-1 measurements before premilking preparation likely would not have wholly prevented this effect because early pretrials indicated that teat contractions began after contact with the ultrasound cup, thus impairing consistent measurement. Additionally, it was preferable to clean teats before ultrasonography to allow for clear imaging. Efforts were made to match 
the normal routine of the cows as much as possible, but some alterations had to be made to accommodate the nature of the study.

\section{CONCLUSIONS}

The increase in TCL immediately after milking at t0 and its sustained elevation above its premilking value throughout the 8-h milking interval suggest that teat tissue is in a state of near-constant remodeling in cows milked 3 times per day. Teat canal diameter dimensions did not change meaningfully during the milking period in this study, and further refinement of the teat canal diameter measuring technique is warranted to improve consistency and decrease variability across different study methods. Future research should directly compare the relationship between postmilking changes in teat canal dimensions and teat canal penetrability to better assess a cow's risk for acquiring new IMI during the milking interval. This research should also explore relationships between teat characteristics, hyperkeratosis, and mastitis risk.

\section{ACKNOWLEDGMENTS}

This project was supported by the Clinical Fellowship Program from Cornell University College of Veterinary Medicine and by the Charitable Trust of Cornell University, College of Agriculture and Life Sciences. The authors thank the staff at the Cornell Teaching Dairy Barn (Ithaca, NY). We thank Iveta Szencziová (Ministry of Agriculture and Rural Development, Bratislava, Slovakia) for providing details regarding the image analysis in Szencziová et al. (2013). We acknowledge the technical assistance of Julio O. Giordano (Department of Animal Science, Cornell University) with the ultrasound device. This manuscript has been greatly improved by the thoughtful comments of an anonymous reviewer.

\section{REFERENCES}

Ahmadzadeh, A., F. Frago, B. Shafii, J. C. Dalton, W. J. Price, and M. A. McGuire. 2009. Effect of clinical mastitis and other diseases on reproductive performance of Holstein cows. Anim. Reprod. Sci. 112:273-282. https://doi.org/10.1016/j.anireprosci.2008.04.024.

Bar, D., L. W. Tauer, G. Bennett, R. N. González, J. A. Hertl, Y. H. Schukken, H. F. Schulte, F. L. Welcome, and Y. T. Gröhn. 2008. The cost of generic clinical mastitis in dairy cows as estimated by using dynamic programming. J. Dairy Sci. 91:2205-2214. https:// doi.org/10.3168/jds.2007-0573.

Beaudeau, F., V. Ducrocq, C. Fourichon, and H. Seegers. 1995. Effect of disease on length of productive life of French Holstein dairy cows assessed by survival analysis. J. Dairy Sci. 78:103-117. https: //doi.org/10.3168/jds.S0022-0302(95)76621-8.

Cha, E., J. A. Hertl, Y. H. Schukken, L. W. Tauer, F. L. Welcome, and Y. T. Gröhn. 2013. The effect of repeated episodes of bacteriaspecific clinical mastitis on mortality and culling in Holstein dairy cows. J. Dairy Sci. 96:4993-5007. https://doi.org/10.3168/jds.2012 -6232 .

Chebel, R. C., J. E. P. Santos, J. P. Reynolds, R. L. A. Cerri, S. O. Juchem, and M. Overton. 2004. Factors affecting conception rate after artificial insemination and pregnancy loss in lactating dairy cows. Anim. Reprod. Sci. 84:239-255. https://doi.org/10.1016/j .anireprosci.2003.12.012.

Chrystal, M. A., A. J. Seykora, and L. B. Hansen. 1999. Heritabilities of teat end shape and teat diameter and their relationships with somatic cell score. J. Dairy Sci. 82:2017-2022. https://doi.org/10 .3168/jds.S0022-0302(99)75439-1.

Chrystal, M. A., A. J. Seykora, L. B. Hansen, A. E. Freeman, D. H. Kelley, and M. H. Healey. 2001. Heritability of teat-end shape and the relationship of teat-end shape with somatic cell score for an experimental herd of cows. J. Dairy Sci. 84:2549-2554. https://doi .org/10.3168/jds.S0022-0302(01)74707-8.

Fasulkov, I., N. Vasilev, M. Karadaev, and G. Dineva. 2014. Visualization and measurement of teat structures in Black-and-White cows through ultrasonography. Maced. Vet. Rev. 37:89-93.

Franz, S., M. Hofmann-Parisot, W. Baumgartner, G. Windischbauer, A. Suchy, and B. Bauder. 2001. Ultrasonography of the teat canal in cows and sheep. Vet. Rec. 149:109-112.

Gleeson, D. E., E. J. O'Callaghan, and M. Rath. 2002. Effect of milking on bovine teat tissue as measured by ultrasonography. Ir. Vet. J. 55:628-632.

Grindal, R. J., A. W. Walton, and J. E. Hillerton. 1991. Influence of milk flow rate and streak canal length on new intramammary infection in dairy cows. J. Dairy Res. 58:383-388.

Gröhn, Y. T., S. W. Eicker, V. Ducrocq, and J. A. Hertl. 1998. Effect of diseases on the culling of Holstein dairy cows in New York State. J. Dairy Sci. 81:966-978. https://doi.org/10.3168/jds.S0022 -0302(98)75657-7.

Gröhn, Y. T., D. J. Wilson, R. N. González, J. A. Hertl, H. Schulte, G. Bennett, and Y. H. Schukken. 2004. Effect of pathogen-specific clinical mastitis on milk yield in dairy cows. J. Dairy Sci. 87:33583374. https://doi.org/10.3168/jds.S0022-0302(04)73472-4.

Guarín, J. F., M. G. Paixão, and P. L. Ruegg. 2017. Association of anatomical characteristics of teats with quarter-level somatic cell count. J. Dairy Sci. 100:643-652. https://doi.org/10.3168/jds.2016 -11459 .

Guarín, J. F., and P. L. Ruegg. 2016. Short communication: Pre- and postmilking anatomical characteristics of teats and their associations with risk of clinical mastitis in dairy cows. J. Dairy Sci. 99:8323-8329. https://doi.org/10.3168/jds.2015-10093.

Hamann, J., and C. Burvenich. 1994. Physiological status of the bovine teat. Bull. Int. Dairy Fed. 297:3-12.

Hamann, J., C. Burvenich, M. Mayntz, O. Osteras, and W. Haider. 1994. Machine-induced changes in the status of the bovine teat with respect to the new infection risk. Bull. Int. Dairy Fed. 297:1322 .

Hamann, J., and G. A. Mein. 1988. Responses of the bovine teat to machine milking: measurement of changes in thickness of the teat apex. J. Dairy Res. 55:331-338. https://doi.org/10.1017/ S0022029900028582.

Hamann, J., and G. A. Mein. 1990. Measurement of machine-induced changes in thickness of the bovine teat. J. Dairy Res. 57:495-505.

Hillerton, J. E., I. Ohnstad, J. R. Baines, and K. A. Leach. 2000. Changes in cow teat tissue created by two types of milking cluster. J. Dairy Res. 67:309-317.

Hodgson, A. S., and F. R. Murdock. 1980. Effect of teat-end shape on milking rate and udder health. J. Dairy Sci. 63(Suppl. 1):118. (Abstr.)

Khol, J. L., S. Franz, D. Klein, D. Lexer, S. Waiblinger, K. Luger, and W. Baumgartner. 2006. Influence of milking technique and lactation on the bovine teat by means of ultrasonographic examination. Berl. Munch. Tierarztl. Wochenschr. 119:68-73.

Klein, D., M. Flock, J. L. Khol, S. Franz, H. P. Stuger, and W. Baumgartner. 2005. Ultrasonographic measurement of the bovine teat: breed differences, and the significance of the measurements for udder health. J. Dairy Res. 72:296-302. https://doi.org/10 .1017/S0022029905000920. 
Martin, L. M., C. Stöcker, H. Sauerwein, W. Büscher, and U. Müller. 2018. Evaluation of inner teat morphology by using high-resolution ultrasound: Changes due to milking and establishment of measurement traits of the distal teat canal. J. Dairy Sci. 101:8417-8428. https://doi.org/10.3168/jds.2018-14500.

McDonald, J. S. 1975. Radiographic method for anatomic study of the teat canal: Changes between milking periods. Am. J. Vet. Res. $36: 1241-1242$.

Mein, G. A. 2012. The role of the milking machine in mastitis control. Vet. Clin. North Am. Food Anim. Pract. 28:307-320. https://doi .org/10.1016/j.cvfa.2012.03.004.

Mein, G. A., F. Neijenhuis, W. F. Morgan, D. J. Reinemann, J. E. Hillerton, J. R. Baines, I. Ohnstad, M. D. Rasmussen, L. Timms, J. S. Britt, R. Farnsworth, N. Cook, and T. Hemling. 2001. Evaluation of bovine teat condition in commercial dairy herds: 1 . Noninfectious factors. Pages 347-351 in Proc. 2nd Int. Symp. Mastitis and Milk Quality, Vancouver, BC, Canada. Natl. Mastitis Counc. Inc., Madison, WI.

NRC. 2001. Nutrient Requirements of Dairy Cattle. 7th rev. ed. Natl. Acad. Press, Washington, DC.

Neijenhuis, F., H. W. Barkema, H. Hogeveen, and J. P. Noordhuizen. 2000. Classification and longitudinal examination of callused teat ends in dairy cows. J. Dairy Sci. 83:2795-2804. https://doi.org/10 $.3168 /$ jds.S0022-0302(00)75177-0.

Neijenhuis, F., H. W. Barkema, H. Hogeveen, and J. P. Noordhuizen. 2001b. Relationship between teat-end callosity and occurrence of clinical mastitis. J. Dairy Sci. 84:2664-2672. https://doi.org/10 .3168/jds.S0022-0302(01)74720-0.

Neijenhuis, F., G. H. Klungel, and H. Hogeveen. 2001a. Recovery of cow teats after milking as determined by ultrasonographic scanning. J. Dairy Sci. 84:2599-2606. https://doi.org/10.3168/jds .S0022-0302(01)74714-5.

O'Shea, J. 1987. Machine milking and mastitis. Section 2: Machine milking factors affecting mastitis. A literature review. Bull. Int. Dairy Fed. 215:5-32.

Paulrud, C. O. 2005. Basic concepts of the bovine teat canal. Vet. Res. Commun. 29:215-245.

Paulrud, C. O., S. Clausen, P. E. Andersen, and M. D. Rasmussen. 2005. Infrared thermography and ultrasonography to indirectly monitor the influence of liner type and overmilking on teat tissue recovery. Acta Vet. Scand. 46:137-147.

Penry, J. F., J. Upton, G. A. Mein, M. D. Rasmussen, I. Ohnstad, P. D. Thompson, and D. J. Reinemann. 2017. Estimating teat canal cross-sectional area to determine the effects of teat-end and mouthpiece chamber vacuum on teat congestion. J. Dairy Sci. 100:821-827. https://doi.org/10.3168/jds.2016-11533.

Rollin, E., K. C. Dhuyvetter, and M. W. Overton. 2015. The cost of clinical mastitis in the first 30 days of lactation: An economic modeling tool. Prev. Vet. Med. 122:257-264. https://doi.org/10.1016/j .prevetmed.2015.11.006.

Ruegg, P. L. 2012. Mastitis in dairy cows. Vet. Clin. North Am. Food Anim. Pract. 28:xi-xii. https://doi.org/10.1016/j.cvfa.2012.04.003.

Santos, J. E. P., R. L. A. Cerri, M. A. Ballou, G. E. Higginbotham, and J. H. Kirk. 2004. Effect of timing of first clinical mastitis occurrence on lactational and reproductive performance of Holstein dairy cows. Anim. Reprod. Sci. 80:31-45. https://doi.org/10.1016/ S0378-4320(03)00133-7.

Schober, P., C. Boer, and L. A. Schwarte. 2018. Correlation coefficients: Appropriate use and interpretation. Anesth. Analg. 126:1763-1768. https://doi.org/10.1213/ANE.0000000000002864.
Schukken, Y. H., J. Hertl, D. Bar, G. J. Bennett, R. N. González, B. J. Rauch, C. Santisteban, H. F. Schulte, L. Tauer, F. L. Welcome, and Y. T. Gröhn. 2009. Effects of repeated gram-positive and gram-negative clinical mastitis episodes on milk yield loss in Holstein dairy cows. J. Dairy Sci. 92:3091-3105. https://doi.org/ 10.3168/jds.2008-1557.

Schultze, W. D., and S. C. Bright. 1983. Changes in penetrability of bovine papillary duct to endotoxin after milking. Am. J. Vet. Res. 44:2373-2375.

Seegers, H., C. Fourichon, and F. Beaudeau. 2003. Production effects related to mastitis and mastitis economics in dairy cattle herds. Vet. Res. 34:475-491. https://doi.org/10.1051/vetres:2003027.

Strapák, P., E. Strapáková, M. Rušinová, and I. Szencziová. 2017. The influence of milking on the teat canal of dairy cows determined by ultrasonographic measurements. Czech J. Anim. Sci. 62:75-81. https://doi.org/10.17221/68/2015-CJAS.

Szencziová, I., P. Strapák, L. Stádník, J. Ducháček, and J. Beran. 2013. Relationship of udder and teat morphology to milking characteristics and udder health determined by ultrasonographic examinations in dairy cows. Ann. Anim. Sci. 13:783-795. https://doi .org/10.2478/aoas-2013-0053.

Upton, J., J. F. Penry, M. D. Rasmussen, P. D. Thompson, and D. J. Reinemann. 2016. Effect of pulsation rest phase duration on teat end congestion. J. Dairy Sci. 99:3958-3965. https://doi.org/ $10.3168 /$ jds.2015-10466.

Weiss, D., M. Weinfurtner, and R. M. Bruckmaier. 2004. Teat anatomy and its relationship with quarter and udder milk flow characteristics in dairy cows. J. Dairy Sci. 87:3280-3289. https://doi.org/ 10.3168/jds.S0022-0302(04)73464-5.

Wieland, M., J. M. Melvin, P. D. Virkler, D. V. Nydam, and W. Heuwieser. 2018b. Technical note: Development and evaluation of a standard operating procedure for ultrasound-based measurements of teat canal dimensions in dairy cows. J. Dairy Sci. 101:15181523. https://doi.org/10.3168/jds.2017-13326.

Wieland, M., D. V. Nydam, and P. D. Virkler. 2017. A longitudinal field study investigating the association between teat-end shape and two minute milk yield, milking unit-on time, and time in low flow rate. Livest. Sci. 205:88-97. https://doi.org/10.1016/j.livsci .2017.09.011.

Wieland, M., P. D. Virkler, A. H. Borkowski, N. Älveby, P. Wood, and D. V. Nydam. 2018a. An observational study investigating the association of ultrasonographically assessed machine milkinginduced changes in teat condition and teat-end shape in dairy cows. Animal https://doi.org/10.1017/S1751731118001246.

Williams, D. M., and G. A. Mein. 1982. Review: Physical and physiological factors affecting milk flow rate from the bovine teat during machine milking. Pages 42-74 in Proc. Conf. Dairy Production from Pasture, Hamilton, New Zealand. K. L. Macmillan and V. K. Taufa, ed. New Zealand Society of Animal Production, Hamilton, New Zealand.

Zecconi, A., J. Hamann, V. Bronzo, and G. Ruffo. 1992. Machineinduced teat tissue reactions and infection risk in a dairy herd free from contagious mastitis pathogens. J. Dairy Res. 59:265-271.

Zwertvaegher, I., S. De Vliegher, B. Verbist, A. Van Nuffel, J. Baert, and S. Van Weyenberg. 2013. Short communication: Associations between teat dimensions and milking-induced changes in teat dimensions and quarter milk somatic cell counts in dairy cows. J. Dairy Sci. 96:1075-1080. https://doi.org/10.3168/jds.2012-5636. 